\title{
Instructional and Business Continuity Amid and Beyond COVID-19 Outbreak: A Case Study from the Higher Colleges of Technology
}

\author{
Abdullatif AlShamsi ${ }^{1}$, Jihad Mohaidat ${ }^{1}$, Noura Al Hinai ${ }^{1}$ \& Ahmed Samy ${ }^{1}$ \\ ${ }^{1}$ Higher Colleges of Technology, Abu Dhabi, United Arab Emirates \\ Correspondence: Ahmed Samy, Higher Colleges of Technology, P.O.Box: 25026, Abu Dhabi, United Arab \\ Emirates.
}

Received: July 2, 2020

Accepted: September 1, 2020

Online Published: September 18, 2020

doi:10.5430/ijhe.v9n6p118

URL: https://doi.org/10.5430/ijhe.v9n6p118

\begin{abstract}
With the announcement of COVID-19 as a pandemic, and the call for social distancing, academic institutions reacted by shutting campuses and calling for the shift to virtual online delivery. In the United Arab Emirates (UAE) Higher Colleges of Technology (HCT), this study was designed in an effort to sustain success in these global challenging times that is informed by strategic foresight.

HCT called for an all-online delivery starting March 22, 2020 after a two-day pilot in the preceding week. HCT readiness is a result of orchestrating: an ecosystem perspective on digital transformation, a forward-looking institutional strategy that has technology utilization as a major pillar, an education technology strategy, and a comprehensive set of intelligent learning tools.

Forward-looking scenarios were designed based on two critical uncertainties: (1) COVID-19 longevity and (2) socio-economic disruption. These scenarios were named: Divine Mercy, Recovery Mode, New Norm, and Survival of the Fittest. Subsequently, the features of each scenario are assessed for implications on HCT's business and support operations, and the proactive strategies are documented to cope with these implications.

During the full online delivery mode period, HCT surveys result reported $86 \%$ satisfaction amongst its faculty and 54\% amongst its student body, delivered 234000 hours through 61000 online classes, and delivered over 21000 hours of online professional development (PD) sourced from HCT's Learning Management System. Over the same period, more than 1900 non-faculty employees were-running business as usual from home reported via online attendance and daily/weekly task forms.

Envisioning future scenarios and preparing the organization for them is a practice that should be deployed in parallel to emergency response efforts to ensure successful business continuity.
\end{abstract}

Keywords: higher education, strategy, business continuity, future scenarios, COVID-19, UAE

\section{Introduction}

Upon declaring the COVID-19 outbreak as a pandemic and implementing social distancing measures, the Ministry of Education in the United Arab Emirates (UAE) directed all schools and higher education institutions to transform their teaching and learning activities to a distance-learning mode. The Higher Colleges of Technology (HCT), the largest higher education provider in the UAE, initiated an emergency response and business continuity taskforce to ensure smooth and successful transition not only to distance learning but also throughout the entire system of HCT.

HCT was founded by a Federal Decree issued in 1988 with a mandate to provide applied higher educational programs to a large student body of more than 20000 students in 16 campuses across the Emirates. HCT offers work-integrated, English-taught programs in Applied Media, Business, Computer Information Science, Engineering Technology \& Sciences, Health Sciences, Education, Military \& Security and Professional Careers at various levels. All programs are designed in consultation with business and industry partners to ensure its programs and curricula are relevant to the job market demand of skills and competencies.

Leveraging emerging technologies such as Artificial Intelligence, Blockchain, and Big Data to digitize the educational system at HCT is a core focal strategy: covering all aspects of teaching and learning that includes all areas of technology-enhanced learning, electronic assessment, library services, intelligent learning systems, and digital services and infrastructure. This educational technology strategy is aligned with a number of national 
strategies such as the National Plan for UAE Smart Government Goals (Telecommunications Regulatory Authority, 2015), UAE National Innovation Strategy (Prime Minister's Office, 2015), UAE Artificial Intelligence Strategy (Prime Minister's Office, 2017), and the Fifty-Year Charter (Prime Minister's Office, 2019), which calls for leveraging technologies to deliver personalized learning for each and every citizen of the UAE.

When it comes to online learning, several published statistics have indicated a positive trend in numbers of students enrolling in some form of online learning (Allen and Seaman, 2016). Additionally, a recent study found almost two-thirds of college and university administrators perceived online education as critical to the institution's long-term strategy and success (Allen and Seaman, 2016). Many factors influence the quality of online education and the learning experience, which has been a long-standing topic for consideration (Twigg, 2001; Yang and Cornelious, 2004). Several research studies comparing face-to-face classroom-based instruction with online instruction have found no significant differences on a number of variables related to student engagement and success measures (Johnson et al., 2000; Navarro and Shoemaker, 1999; Smeaton and Keogh, 1999). The same conclusion was true for distance education effectiveness versus that of face-to-face education. As evident by research studies, even indicated distance education, when it is the only option available, can successfully replace face-to-face instruction (Bernard et al., 2004; Cavanaugh, 2001; Moore, 1994).

An evaluation of evidence-based practices in online learning conducted by U.S. Department of Education and guided by extensive literature review, attempted to develop a conceptual framework identifying three key influential components on the quality of online learning. These were the types of learning activities introduced as a replacement or enhancement to conventional face-to-face, the pedagogical approach, and type of communication as synchronous or asynchronous (Means et al., 2009). Failing to address online learning holistically could very well lead to adverse results exemplified in notable student disengagement, lower retention rates, and ineffective overall online learning experience (Muir et al., 2019). Another study on the development of an instructional strategy framework for online learning environments contended that powerful online learning environments needed to contain a combination of: individual needs assessments, student motivational activities, avoidance of information overload, a real-life context, encouragement of social interaction, hands-on activities, and an increased emphasis on student reflection (Johnson and Aragon, 2003).

An interview conducted by the Oxford Business Group (Alshamsi, 2020) with the President \& CEO of the Higher Colleges of Technology revealed that, from a strategic perspective, digitalization of learning towards what is referred to as Persona 4.0 Strategy was crucial to develop the learner digital persona as one of major components of the Persona 4.0. The other two personas were professional and entrepreneurial personas. The adoption of technology throughout their learning journey, however, was a mandatory prerequisite to the development of their digital persona. This goes beyond mere computer literacy to a holistic digital skills-based development and rapid adoption of new technologies as they emerge (Alshamsi, 2020). With digitization at the core of HCT's strategic transformation, as exemplified in investments incurred over the past five years in people, infrastructure, and technology, these have all come together to facilitate a smooth transition amid the COVID-19 outbreak and its consequences in terms of enforced social distancing measures. Starting with a two-day pilot implementation of a comprehensive distance learning undertaken across the entire system has paved the way to a digital campus environment since March 22, 2020 to-date. The success story this paper aims to explore is its underlying critical success factors, and concludes with a forward-looking perspective of future plausible scenarios and key proactive strategies to action today in preparation for, what might very well be, a longer journey that extends to the upcoming academic year 2020/2021.

\section{Material Studied}

\subsection{Strategic Foresight}

HCT's strategic aspirations were determined in large, by a strategic foresight approach fueled by ongoing scanning of the external environment at the macro and micro levels, which ultimately led to the formulation of HCT's strategic plan referred to as HCT 4.0 in alignment with the fourth industrial revolution and its impact on higher education. A number of internal and external factors led to the initiation of HCT 4.0, but primarily, it was the Dubai's Fifty-Year Charter, which called for personalized education, that enabled learners to take personal ownership of their lifelong learning. This Charter also called for the establishment of economic and creative free zones in universities, to allow students to carry out entrepreneurial and experiential learning activities that may ultimately lead to the emergence of high-tech startups and the graduation of entrepreneurs. Other external trends of great impact on higher education at a global scale included a refocus on Competency Based Education (CBE) called by employers for a movement towards micro-credentialing and associated forms of digitally enabled assessments. The CBE reforms are likely to have an impact on the way teaching and learning is conducted on digital platforms to enable students to progress at 
their own pace, rather than at the prescribed pace dictated by the structure of the course or program they are studying. The future of UAE universities is anticipated to focus more on student contributions to the social and economic development of the country, while leveraging technology to transform its core business activities, as opposed to continuing as traditional teaching and learning institutions.

The intersection of these business and technology trends creates six themes or patterns for higher education institutions to inform their strategic developments and investments (Costello, 2019).

A brief description of each theme is provided as follows:

1) The Data-driven Academy. The growing interest in using data to solve decision problems and to guide strategy in higher education.

2) Skills and Employment. Higher education institutions need to play more of a role in helping society meet skills needs, preparing students for the world of work and ensuring they are successful in workplace endeavors.

3) Security and Integrity. Trending technologies, such as next-generation security and risk management, as well as digital credentials and smart campuses reflecting a drive toward security and integrity.

4) Strained Business Models. Trending technologies, such as predictive analytics, digital credentials and cross-life-cycle Customer Relationship Management (CRM), are indirectly reflecting institutional efforts to cope with strains on the business model or finding new ones.

5). Space and Place. Higher education institutions are trying to balance the physical with the virtual and emphasize each in ways that support the business model and bring value and engagement to stakeholders of many types.

6). The Student Experience. The 'student experience' is a term encompassing all aspects of student engagement with the institution, from recruitment and enrollment, formal classes, and programs, to social interactions and campus life, as well as post-graduation interaction with the institution.

The use and application of digital technology to enhance learning is transforming the way students learn. Developments in online education, data analytics, virtual and augmented reality, artificial intelligence, and machine learning are leading to blended learning, flipped classroom and other such educational strategies of the future (Smyrnova-Trybulska, 2019). This was a key driver to a couple of HCT's strategic objectives: (1) to embed intelligent and innovative teaching and learning methods and (2) to leverage technology to enable institutional growth and development. Yet, for digitalization of education to become as effective as envisioned, the authors believe that the following critical success factors needed to be in place:

1) Solid integration of curricular activities with supporting technology platforms.

2) An effective design and empowerment of courses and programs that encourages self-directed learning.

3) Savvy and trained faculty and students in the use of technology for learning.

4) An effective assessment approach of students' achievement of course and program learning outcomes on digital platforms.

5) An ecosystem perspective that drives and stimulates ongoing engaging learning experiences.

Technology is also enabling creative and interactive content development (Palmer and Devitt, 2007). Learners are collaborating more effectively with other learners and with faculty in the development of their assignments. These are the first steps towards more personalized learning that these technologies will enable and enhance. Blended Learning approaches use multiple methods to deliver learning by combining face-to-face interactions with interactive online activities in a seamless and complementary flow to facilitate an engaging student experience (Garrison and Kanuka, 2004). However, the balance between online and face-to-face elements depends on students' learning goals and the educational context where teaching and learning interactions happen.

HCT has invested in educational technologies to develop its first digital campus. For instance, e-Portfolios have entered the HCT strategic radar to ensure that learners benefit from the flexibility and transferability of their portfolios during the journey with HCT and beyond in order to demonstrate skills and competencies gained to prospective employers. Blackboard, the Learning Management System (LMS) adopted at HCT, is the hub of learning by students and feedback to them by faculty. However, one of the avenues currently being addressed is its integration with other platforms like digital badging, in order to create a one-stop-shop teaching and learning environment where digital badges can be issued for distinct phases of learning achievement (Higher Colleges of Technology Education Technology Focal Strategy 2017-2021, 2019). 
HCT is currently undertaking a 'Digital Micro-Credentials' initiative in formal higher education settings where the current stage is to research and recommend a detailed framework, job specific portfolio and Digital Credential platforms. One ultimate objective is to implement and connect a digital credentials platform with employers' systems through HCT's Career Exploration Centers. Virtual simulation is another technology HCT is exploring to offer students opportunities to make mistakes without real-world repercussions, experiencing situations that may be practically difficult or dangerous, and being able to receive immediate feedback. The use of virtual and augmented reality technologies to develop simulations of real-world scenarios enables students to interact, engage, learn, and apply in unprecedented ways. To deliver all of the above technologies, adoption of a good and flexible technical infrastructure is required with the capacity and the ability to adapt and scale to different contexts whilst ensuring interoperability, the capability to exchange information with other major systems.

\section{Methods}

\subsection{An Ecosystem Perspective}

Being proactive in terms of executing a well-planned transformation to achieve a given target or goal will ensure with large degree of certainty the success of achieving the said goal. During the execution, HCT went through a relaxed learning curve checking the milestones, key performance indicators, outcomes and extensive reviews. In this aspect, HCT had strategized early on digital transformation, technology-rich education environment for online delivery and anywhere anytime access as a key pillar in its strategy and its education technology focal strategy. Since early 2016, HCT started to build and execute a plan for full online delivery of its course offerings. This was driven by the emerging trend of $\mathrm{CBE}$ and micro-credentials to the point that traditional academic credentials were deemed irrelevant by some of the largest corporations in the world like Google, Apple and Ernst \& Young.

HCT designed a multi-layered ecosystem for its digital transformation with an aim to improve organizational readiness and agility in delivering effective teaching and learning activities. This multi-layered ecosystem leverages the following organizational capabilities with each playing a pivotal role as described below:

1) Institutional strategic alignment and supportive governance. The vocation of HCT as a key player in the nationwide smart education ecosystem is crystalized in HCT 4.0 Strategy with the ultimate strategic outcomes of graduating technical leaders and companies while ensuring a learning opportunity for every citizen.

2) An organizational structure that strategizes educational technologies as one of its key pillars. HCT's organizational structure combines three functions under one division with a direct reporting line to the President \& CEO titled Education Technologies (EdTech) division. This division encompassing three underlying departments: (1) Intelligent Learning Systems, (2) Digital Technologies, and (3) Data \& Knowledge Management (KM) enabling large scale efficiencies and improved responsiveness.

3) Resilient and agile infrastructure. A solid Information Technology infrastructure enables around the clock access to all applications in demand such as LMS, e-library, portals, and mobile apps, a system with 99.9\% availability and bandwidth loading of no more than $20 \%$ with a solid security enablement inclusive of multifactor authentication for all key applications.

4) Dedicated professional development teams. Dedicated team offering Professional Development (PD) to faculty and supporting roles in Teaching.

5) Large catalogue of digital content. Dedicated resources for digital content development with full adoption of digital textbooks as primary sources of course delivery and library access.

6) Decision making powered by Big Data. Every single data point in all data basis whether structured or unstructured to be pushed to a data lake that interfaces with data warehousing and business intelligence tools along with data mining tools enabled by artificial intelligence.

7) Cross-institutional alignment and partnerships. Close collaboration with administrative government entities and regulatory bodies as well as established solid collaborations with telecom and technology providers.

8) Wide spectrum of student and faculty applications. Applications that range from LMSs to the latest student information systems (SIS) powered by adaptive technology platforms and native smart applications.

9) Students and faculty Experience in distance and blended learning. Since 2017, HCT has implemented a network of 26 Blended Learning Classrooms, technology-enhanced educational spaces designed for delivering interactive lectures to multiple campuses simultaneously. This delivery mode optimized faculty utilization and significantly expanded course delivery across HCT's 16 campuses. 
10) A system-wide technical support service to manage end-to-end incidents life cycle. Dedicated support onsite and offsite resources to intercept and timely resolve escalated issues and incidents.

All of the above capabilities strengthened HCT's position towards a smooth transition to operate fully online early before COVID-19 outbreak.

\subsection{Educational Technologies Investments}

In order to ensure the success of emerging technology into HCT's academic support operations and the restructuring initiative combining faculty readiness, technology-based teaching \& learning, and information technology under the EdTech division, three departments were created: (1) Digital Technologies (DT), (2) Intelligent Learning Systems (ILS), and (3) Data \& Knowledge Management (KM). The purpose of this restructuring was to bring coherence, alignment, and functional integration to deliver the Education Technologies focal strategy. Below is a brief description of the role of each of these departments in leveraging emerging technologies from an integrated ecosystem perspective. The restructuring appeared to be one of the critical success factors underpinning HCT's seamless transition to full online operations in response to COVID-19 outbreak.

1) Digital Technologies (DT). Traditionally known as the Information Technology (IT) department, it was transformed under the EdTech Division to become the backbone of operations with the ultimate objective of ensuring all digital infrastructure components (architecture, network, storage, security, integration, etc.) were empowering all applications operated by academics and support functions. HCT infrastructure was equipped with a robust fully redundant architecture at various levels to enable digital online teaching and learning experience for faculty and students, and to ensure $100 \%$ availability of all services. To enable full remote working and distance learning environments, a managed service approach was adopted with industry partners to maintain systems availability where performance was monitored against service level agreements.

Furthermore, Virtual Private Network (VPN) tools with Secure Multi Factor Authentication were deployed to allow staff and faculty remote access to HCT's digital ecosystem. Applications like Cisco Jabber, Microsoft Teams, and Zoom were deployed to facilitate work related communications, meetings, and collaborations. Other key technologies were also put in use, such as secure remote access to laboratories and virtual simulated lab environments, to maximize the benefits of the distance-learning journey.

2) Intelligent Learning Systems (ILS). This department oversees the system-wide activities including the LMS Blackboard operations, faculty PD, the digital library, and digital content development. Blackboard has been an invaluable investment for HCT as the main enterprise LMS. HCT has been using Blackboard to deliver teaching and learning activities to students in different modes: face-to-face, blended, and distance learning. HCT is using Blackboard for course delivery management, delivering synchronous live online lectures, online assessments, remote proctoring, and providing access to all digital textbooks. Blackboard has fostered the online delivery of classes and assessments by facilitating real-time virtual engagement between faculty and students, faculty and academic divisions, faculty and PD/LMS teams. It also facilitated both synchronous and asynchronous delivery and provide faculty with online communities and forums to share good practices and allow for instant feedback on course delivery and assessments.

Another mandate of the ILS department was to nurture an environment that promotes faculty PD through continuous upskilling, mentoring, and coaching, with a particular emphasis on the use of Blackboard Learn and its integrated technologies. This PD in instruction practice spanned eight key areas: assessment, curriculum development, facilitation, designing learning activities, leadership, teacher development, research, and teaching innovation. Noteworthy, the HCT faculty PD practices are AdvanceEd-accredited. Furthermore, through the rollout of Blackboard's Digital Teaching and Learning Series (eTeacher Training Program) in September 2019, HCT became a pioneer amongst its peers in digital teaching and learning. This undertaking was in alignment with Blackboard's assessment of HCT's digital credentials to establish the HCT as the first certified Digital Center of Excellence in the region.

3) Data \& Knowledge Management. This department oversees institutional data and knowledge management practices with the ultimate purpose of reinforcing informed decision-making capabilities. A good example is the use of data mining in identifying students at risk as a mean to control retention rates and improve their academic standing. A key responsibility of this department is to oversee the HCT's data lake where all institutional data, structured and unstructured, are hosted. The data lake represents a system-wide data warehousing solution empowered by sophisticated business intelligence tools. 


\section{Results and Discussion}

\subsection{Smooth Transition amid COVID-19 Outbreak}

Previous sections on HCT's ecosystem readiness and technology investments serve as a preamble to what was a smooth transition to full online operations due to the COVID-19 outbreak. During the full rollout of HCT's online operations from March 22 to May 7 2020, the big data systems were deployed to collect all possible data points to measure performance, collect feedback, and devise corrective actions as needed. Staff and faculty satisfaction and perception of this online experience were assessed relative to the traditional in class instruction. The data systems started with a two-day pilot implementation of online operations to assess readiness before going fully online. With over 22,000 students and 2,500 faculty and staff all working from home, key components of the ecosystem readiness assessment were digital infrastructure resilience, network availability, and network utilization.

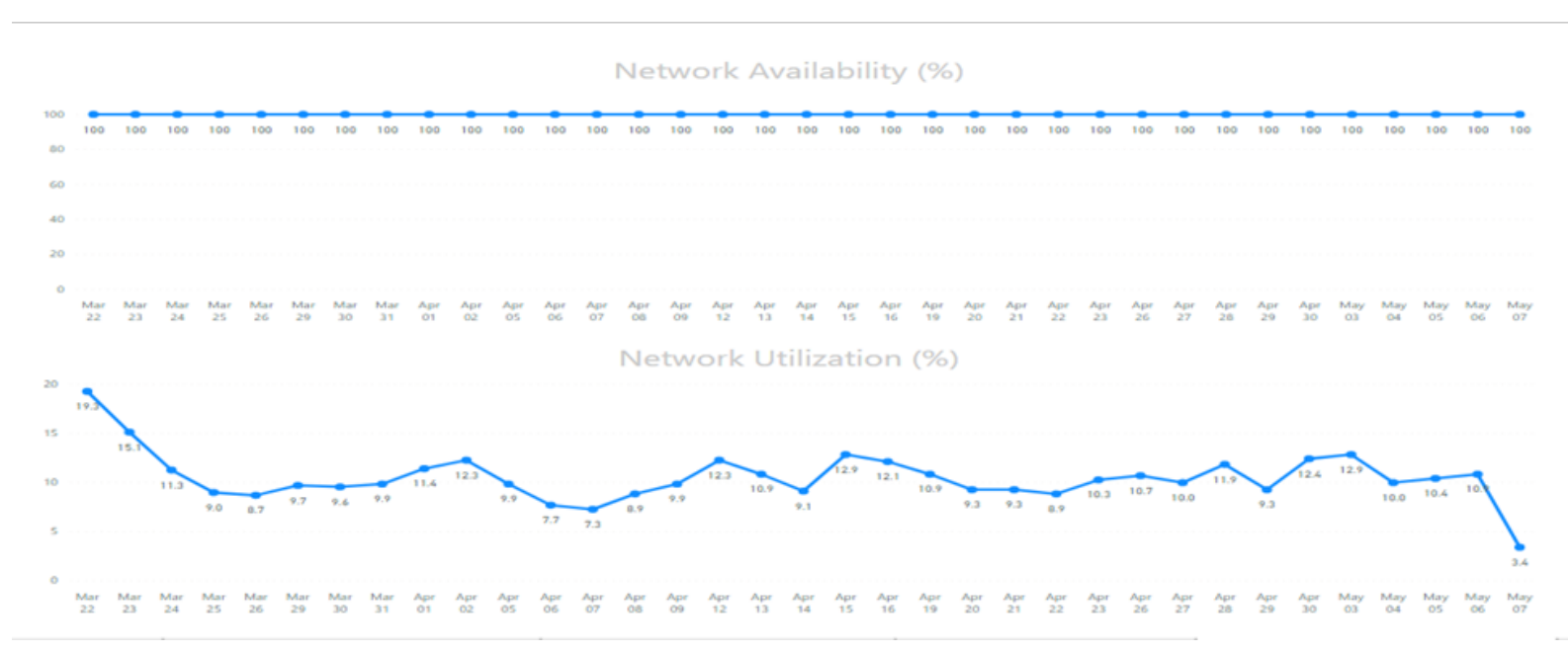

Figure 1. Network Availability and Utilization

As illustrated in Figure 1, the network availability rate was at $100 \%$ with no downtime, and the network utilization was in the range of $3.4 \%$ to $19.3 \%$ with an average of $10 \%$. Such network performance measures provided confidence in the robustness, agility, and capability of the infrastructure to handle the expected load and beyond. Throughout the entire online operations period, over 234000 hours of online teaching was delivered, over 61,000 live online classes were conducted with a record $90 \%$ attendance rate, over 1500000 successful student logins were records, and over 21,000 professional development faculty-hours were delivered.

It was crucial to gauge both student and faculty perceptions and satisfaction during the pilot phase, to assess their readiness and identify critical gaps that must be fulfilled prior to full-online deployment. The survey was also conducted periodically, during the full-online deployment to evaluate progress from the prospective of both students and faculty, and introduce corrective actions as deemed necessary. As such, a survey was conducted over the two-day pilot phase and covered both faculty and students. The pilot was a full online scale trial of a distance-learning mode. During this pilot phase, classes were delivered as scheduled where faculty were conducting their classes from the classroom while students were at distance. The entire HCT student population had the opportunity to participate in the pilot with over 2,950 classes delivered online and over 100000 unique student logins recorded.

The survey conducted during the full online operation from March 22 to May 7 2020, targeted five main categories, namely: online learning readiness, content evaluation, instructor delivery method, overall experience, and class preference. Different parameters were identified to measure the first three categories in order to identify areas of improvement in each category. For the online learning readiness category, the parameters assessed were as follows: Accessibility of online learning platforms (Blackboard Learn or Zoom), availability of online learning resources (computer and internet service), quality of student engagement during the online class, and students' attendance. As for the content evaluation category, it covered the following parameters: quality of material presented, preparation time for this online lesson, and the quality of student interactions during the lesson. The third and last category in the survey, instructor delivery method, assessed the following parameters: Instructor-students' mutual respect, instructor's feedback, instructor's explanation of concepts, and possibilities of effective and valid online testing. The 
survey measured the level of satisfaction over the following scale: very satisfied, satisfied, neutral, dissatisfied, and very dissatisfied.

The pilot phase survey had a total of 3,260 students and 1,330 faculty responses, while the full online delivery mode survey had a total number of students and faculty responses 47,412 and 10,767 respectively over the full online period.

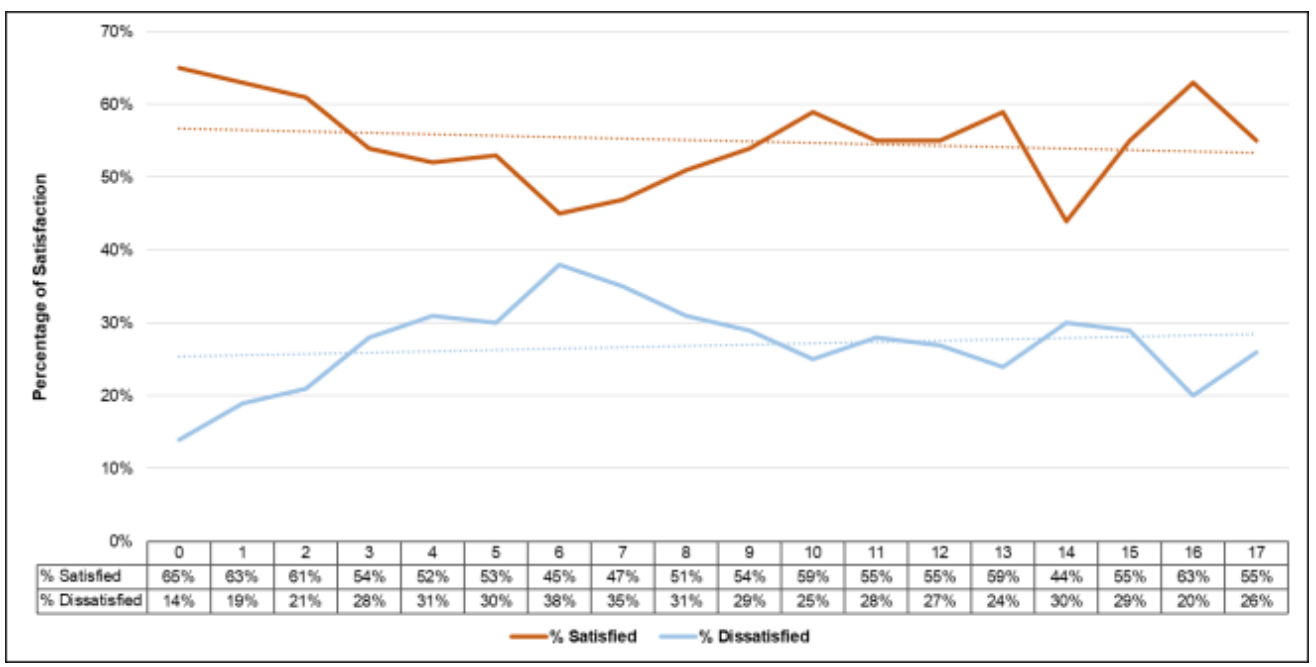

Figure 2. Student satisfaction rate over time for pilot $\&$ full online delivery mode

As illustrated in Figure 2, the overall student satisfaction rate during the pilot phase on day 0 was $65 \%$ with only $14 \%$ dissatisfied. However, the student satisfaction rate between days 1-17 of the full online delivery mode, showed a negative trend in student satisfaction with an average of $54 \%$, and a corresponding positive trend in dissatisfaction with an average of $28 \%$. Regarding preference for face-to-face on campus delivery, $51 \%$ students during the pilot phase preferred face-to-face on campus delivery.

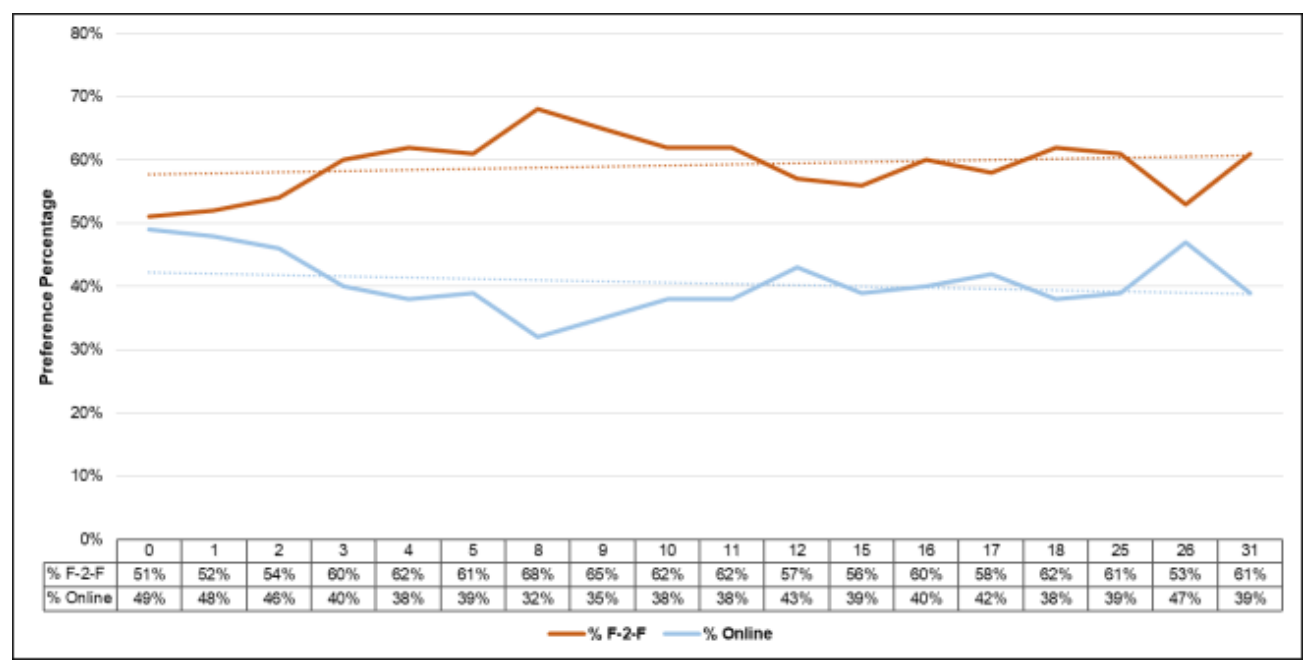

Figure 3. Student preference for Face-to-Face versus Online classes over time for pilot $\&$ full online delivery mode

During the full online delivery phase, students' preference fluctuated with an average of 59\% showing a preference for face-to-face on campus delivery, whereas remaining $41 \%$ preferred online classes, as illustrated in Figure 3.

Turning to faculty, their overall satisfaction rate was $71 \%$ during the pilot phase with only $5 \%$ dissatisfied. 


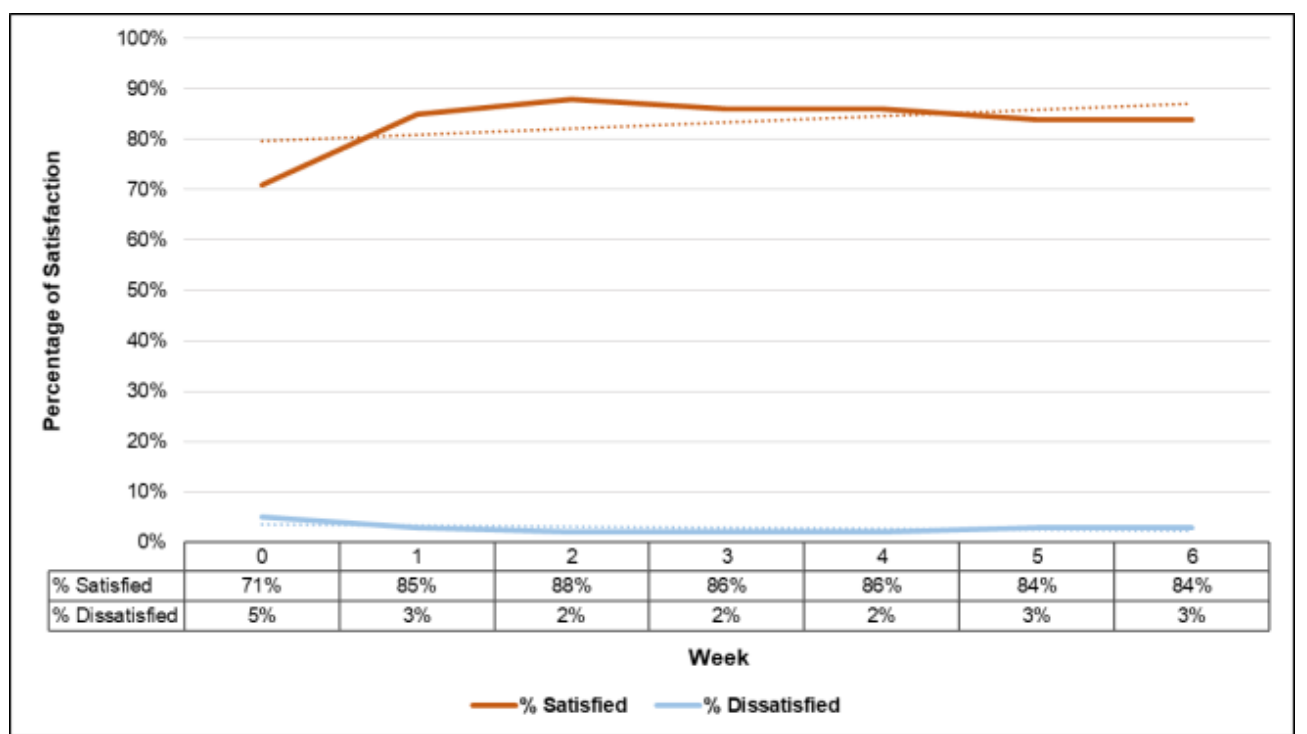

Figure 4. Faculty satisfaction rate over time for pilot $\&$ full online delivery mode

As illustrated in Figure 4, during the full online delivery phase, faculty satisfaction assessed over 6 weeks showed a slightly positive trend with an average satisfaction rate of $86 \%$ while only $2 \%$ were dissatisfied.

The period between pilot implementation and full online delivery mode was used to provide faculty with sufficient professional development to enhance their digital pedagogical skills and confidence in using online tools at their disposal. This was highly appreciated by faculty as evident by an increase in their satisfaction with online teaching from $71 \%$ during the pilot phase to $86 \%$ during the full online delivery mode.

Regarding preference for face-to-face on campus delivery, $57 \%$ of faculty during the pilot phase preferred face-to-face delivery on campus.

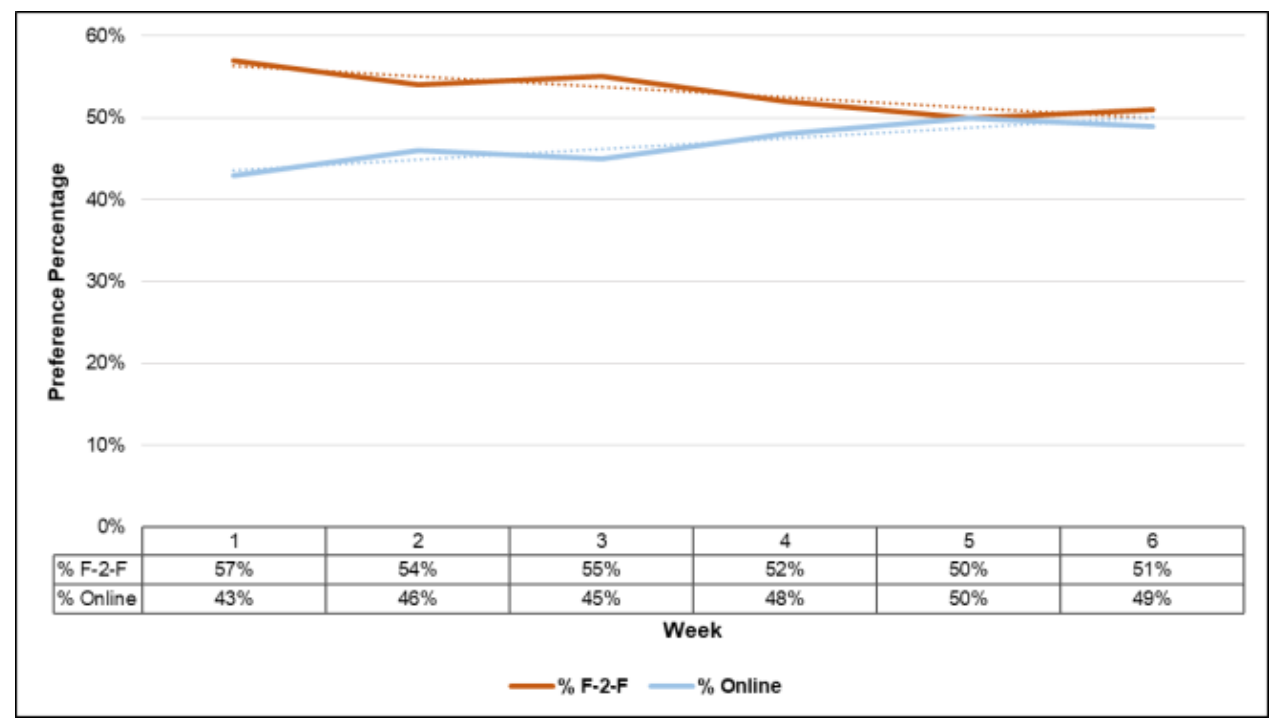

Figure 5. Faculty preference for Face-to-Face versus Online classes over time for pilot $\&$ full online delivery mode

During the full online delivery phase, faculty preference converged to almost a 50/50 split between online and face-to-face delivery with a slight increase in preference for face-to-face, as illustrated in Figure 5.

All neutral responses excluded from the analysis, which represented an average of 19\% during the pilot phase, $65 \%$ of students expressed their satisfaction compared to $71 \%$ of faculty. During full online delivery mode, between days 3 and 6, there was a gradual drop in the student's satisfaction level from 54\% to $45 \%$ mainly due to the requirement to switch on cameras during class time. A policy was then established whereby students were assured that there was no live streaming, and that only faculty were able to see students, and consequently, the satisfaction rate started to 
rise upwards with an overall satisfaction rate of $54 \%$. Overall, $77 \%$ of students felt engaged with their faculty and peers during the online delivery mode, while students and faculty confirmed mutual respect exceeding $91 \%$.

The overall preference results showed almost a 50/50 split between online and face-to-face for both students and faculty due to the following reasons:

1) Nature of the interactive material offered in each course. Content involving hands-on applied practice witnessed a student preference for face-to-face in class delivery, while theoretical knowledge-based content reported students' preferences to online learning.

2) Fatigue. During face-to-face contact hours, students and faculty were able to move around and take breaks in between classes, however, having the same number of contact hours for online classes led to reports of faculty and student fatigue. In addition, faculty reported that it took an average of 2-3 hours to prepare for an online class, relatively longer than what it took to prepare for face-to-face classes. This was in large due to the time it required them to devise interactive visual content to maintain high student engagement level during the synchronous online teaching hours.

3) Maturity of the freshman students. Faculty online delivery significantly exhausted freshmen who did not experience any sort of online teaching in their K-12 education. Students that were more experienced were more satisfied with online delivery, due to the space it provided them for self-directed learning while leveraging class time for discussions and clarifications.

Another critical component worth investigating is the academic assessment approach, where modifications were introduced to better adapt for full online teaching and learning. Such modifications were communicated to all students early April 2020 upon extensive consultation with faculty and the endorsement of HCT's Academic Council. Endorsement entailed an evaluation of each modification against a set of criteria stipulated in HCT's Assessment Quality Framework. These three criteria were validity, reliability, and integrity of the assessment tools proposed while maintaining fairness and equity in assessment amongst all students. 
Table 1. Assessment modifications and additional measures

\begin{tabular}{|c|c|c|}
\hline Category & Assessment Modification & Additional Measure \\
\hline 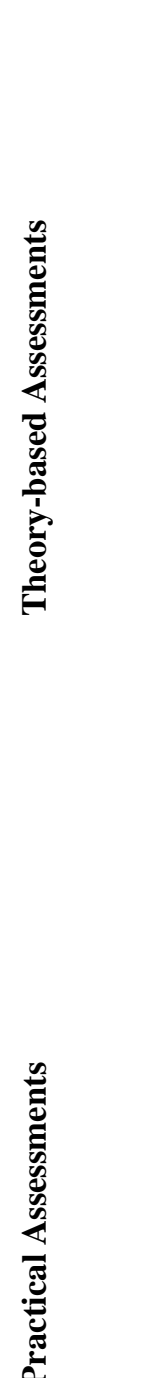 & 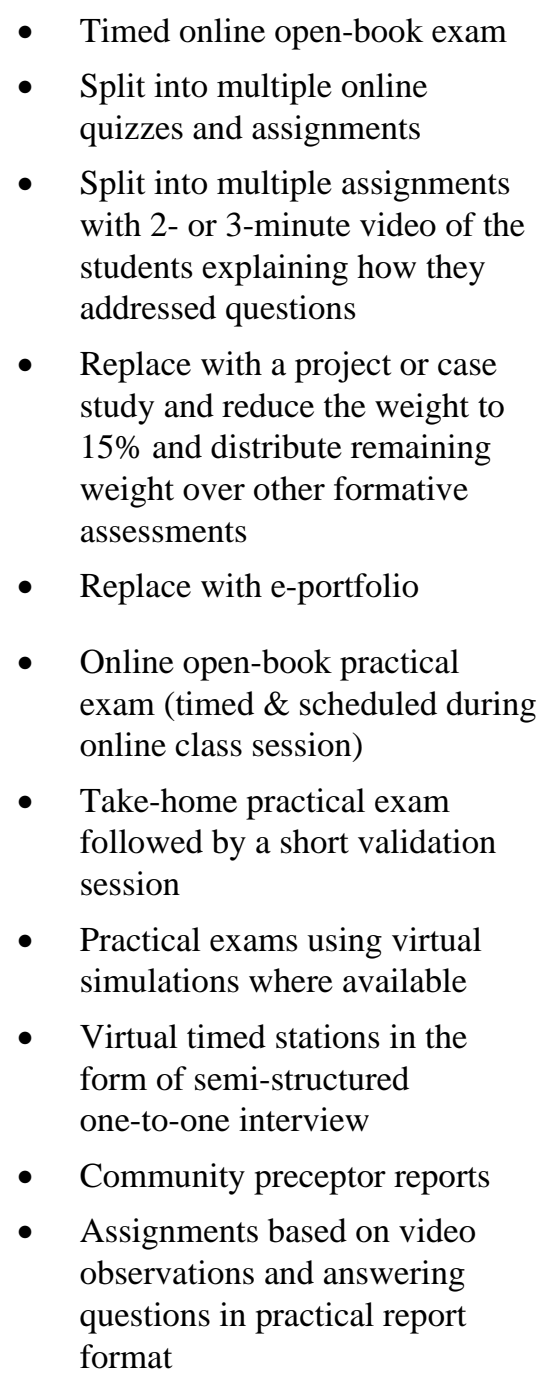 & $\begin{array}{l}\text { - } \begin{array}{l}\text { Prepare alternative scenario-based } \\
\text { questions }\end{array} \\
\text { - } \quad \text { Lab instructors on standby to provide } \\
\text { assistance in remote troubleshooting } \\
\text { - } \quad \text { Oral validation session } \\
\text { - } \quad \text { Online presentation and defence } \\
\text { students to generate reports }\end{array}$ \\
\hline 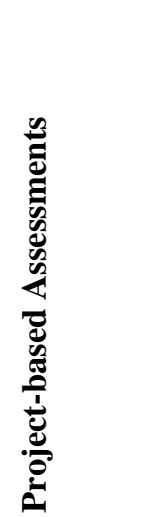 & $\begin{array}{l}\text { Digital submission of projects } \\
\text { and online discussion / } \\
\text { presentation with oral defence } \\
\text { added to verify work } \\
\text { - } \\
\text { Replace projects with multiple } \\
\text { case study analysis } \\
\text { In case prototyping is not } \\
\text { possible, its weight is shifted to } \\
\text { other parts of project marks like } \\
\text { final design report or } \\
\text { presentation }\end{array}$ & $\begin{array}{l}\text { - Students are informed that oral defence } \\
\text { could lower their project grade } \\
\text { substantially if they are unable to respond } \\
\text { successfully to prompts } \\
\text { - Submission of students' work should be } \\
\text { via Blackboard Safe Assign }\end{array}$ \\
\hline
\end{tabular}

As seen in Table 1, these modifications were grouped into three categories along with additional measures adopted for each category to ensure implementation effectiveness.

\subsection{COVID-19 Future Scenarios and Implications}

So far, the transition to full online operations had been seamless and exemplary, and everyone that made it possible from students and faculty to administrative staff and management all contributed to this success. However, the 
COVID-19 global pandemic was still to be considered when preparing for the upcoming Academic Year 2020/2021 and beyond.

The COVID-19 virus led to the closure of all HCT 16 campuses, and forced not just all teaching and learning activities onto online platforms, but extended to student and shared support services. The focal issue that HCT was concerned about was the plausible alternative short-term scenarios, and their implications on its operations in the upcoming Academic Year 2020/2021. Several uncertainties at the macro level for relevance to this focal issue were investigated, and these uncertainties were grouped according to the social, economic, technological, environmental, and political dimensions (Blau et al., 2020). From an economic dimension, the slope of economic recovery and oil price fluctuations were listed as the uncertainties with the highest relevance, while considering the uncertainty of the USD currency instability as a medium relevance. Regarding the social dimension, all three uncertainties pointed to the severity of the pandemic, levels of societal cohesion, societal well-being and quality of life post COVID-19, received high relevance. When it came to the uncertainties related to the technological dimension, discovery of a successful COVID-19 vaccine was classified as high relevance verses Adoption of emerging technologies to aid with crisis response, and Network capacity coping with accelerating demand uncertainties that equally were considered low relevance. As for the environmental dimension, all provided uncertainty, level of adherence to new environmental measures, $\mathrm{CO}_{2}$ emissions post COVID-19, and Strictness of global \& local environmental policies were classified as low relevance. Lastly, for the political dimension, uncertainty related to Government intervention to support the economy was classified as high relevance. As for Level of collaboration within and between countries, and Balance of regulations and privacy uncertainty both considered low relevance.

Out of the above-mentioned uncertainties, two groups of uncertainties were selected and referred to herein as the fundamental uncertainties, that were adopted for plotting the four most plausible scenarios for the UAE. These fundamental uncertainties were:

1) Pandemic Lifecycle. This fundamental uncertainty ranged in dimension from short i.e. 3-6 months, to long i.e. 12-18 months. Despite the extensive efforts globally to develop a vaccine for this virus, predictions were that such a discovery was at least 18 months away at best, and hence the novelty of the virus made it virtually impossible to be able to treat it effectively.

2) Socio-economic State of Disruption. This fundamental uncertainty ranged in dimension from a fragile to resilient society and economy. This uncertainty had the highest impact on HCT and the focal issue being addressed. It was an uncertainty because the pandemic had no precedence in modern times that society has struggled to know how to cope. Reactions of communities varied wildly from extreme fear to extreme acts of solidarity and cohesion towards each other amongst communities.

The intersection of these two fundamental uncertainties drew four alternative plausible scenarios for the UAE: Divine Mercy, Recovery Mode, New Norm, and Survival of the Fittest. Each scenario presents challenges and opportunities for HCT to consider when selecting the most appropriate strategic options. 


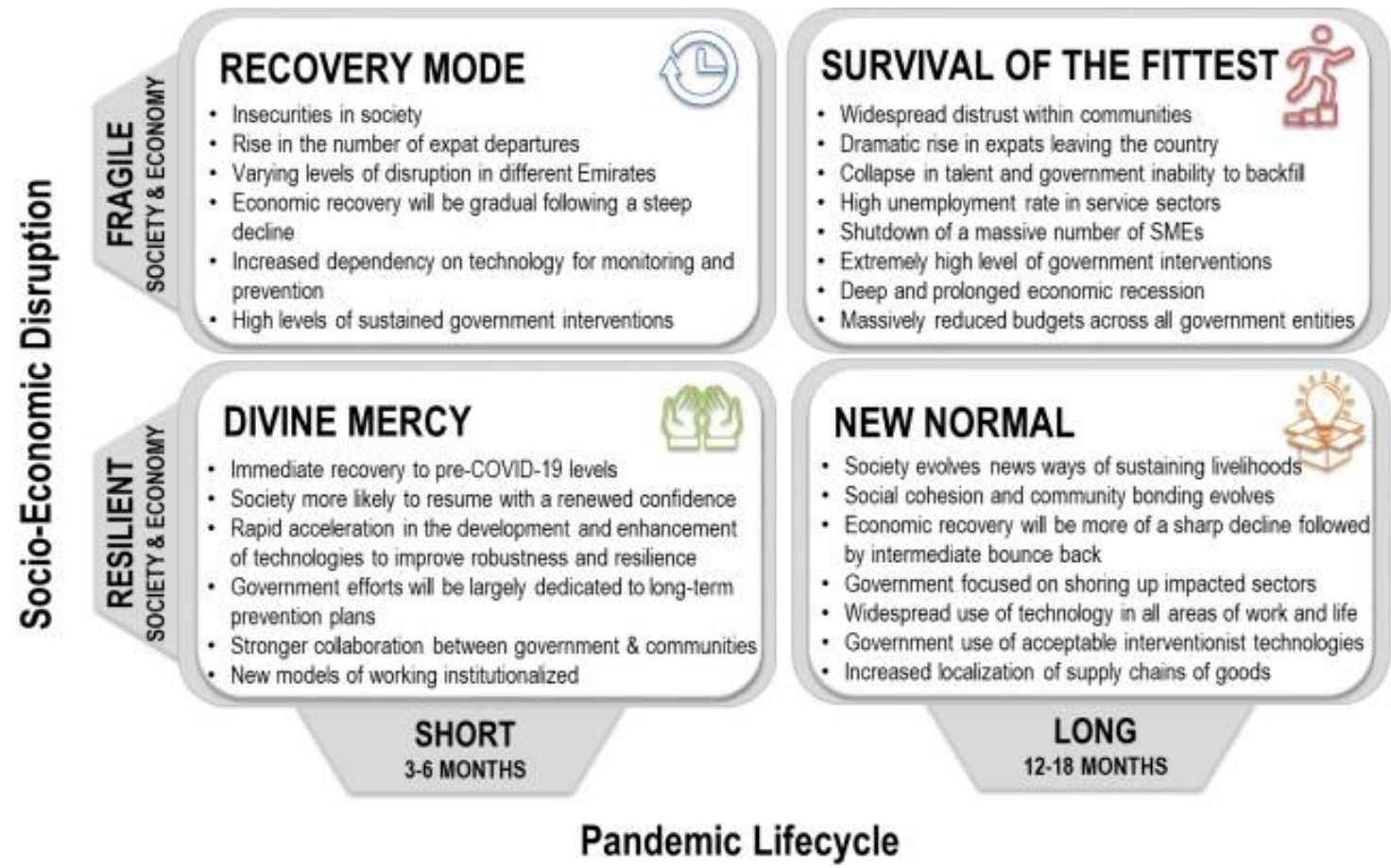

Figure 6. COVID-19 Plausible Scenarios

As illustrated in Figure 6, these scenarios and descriptive features are presented. Each of the above-mentioned scenarios had been analyzed for its potential implications on HCT's operations with particular emphasis on the upcoming academic year 2020/2021. These implications were grouped under four core business and support areas as follows:

1) Student Success. This addresses key strategic outcomes of HCT including graduate employability and entrepreneurship, on-time graduation, students' achievement of program learning outcomes, and student overall satisfaction with their journey and services.

2) Teaching and Learning. This addresses HCT's core business of teaching and learning inclusive of pedagogies, programs choice and offering, curriculum design, teaching with technology, modes of instruction, co-curricular and extra-curricular activities, work integrated learning components, and assessment methodologies.

3) Research and Innovation. This addresses the core business area of HCT inclusive of research and innovation agenda, internal and external funding sufficiency and priorities, faculty research output, and overall appetite for research and innovation.

4) People and Resources. This addresses HCT's human capital professional development needs and attraction mechanisms, physical assets and facilities design and use, and budget constraints and reallocations. 
Table 2. Implications of the Plausible Scenarios

\section{$\begin{array}{llll}\text { Area DIVINE MERCY RECOVERY MODE NEW NORM } & \text { SURVIVAL OF THE }\end{array}$ FITTEST}

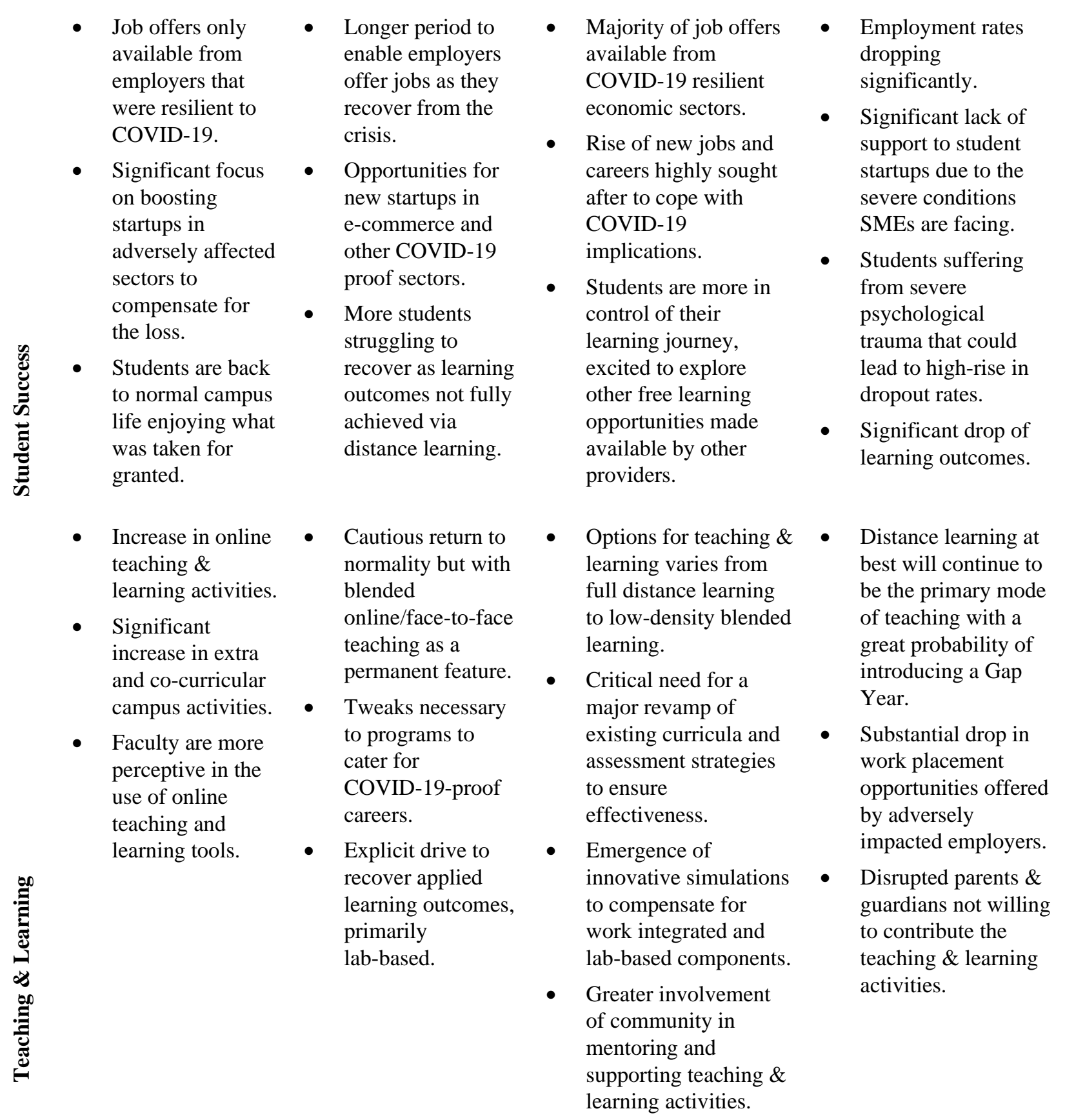




\section{Area DIVINE MERCY RECOVERY MODE NEW NORM}

SURVIVAL OF THE FITTEST

\begin{tabular}{|c|c|c|c|c|}
\hline 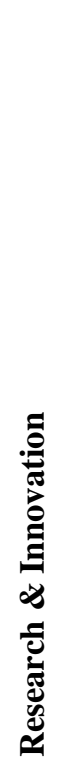 & $\begin{array}{l}\text { Research agenda } \\
\text { may slightly } \\
\text { change to cope } \\
\text { better with future } \\
\text { crises but the } \\
\text { majority of } \\
\text { research and } \\
\text { innovation } \\
\text { activities are back } \\
\text { to normal. }\end{array}$ & $\begin{array}{ll}\text { - } & \text { Post COVID-19 } \\
\text { societal and } \\
\text { economic } \\
\text { challenges } \\
\text { reshaping HCT's } \\
\text { research and } \\
\text { innovation agenda. } \\
\text { - } \\
\text { Significant lack of } \\
\text { research funds } \\
\text { provided by those } \\
\text { industries in } \\
\text { recovery mode. }\end{array}$ & $\begin{array}{l}\text { COVID-19 societal } \\
\text { and economic } \\
\text { challenges reshaping } \\
\text { HCT's research and } \\
\text { innovation agenda. } \\
\text { - Intensified research } \\
\text { and innovative funds } \\
\text { primarily from the } \\
\text { Government in support } \\
\text { of frontline sectors } \\
\text { such as health care and } \\
\text { biotechnology. } \\
\text { Increasing focus on } \\
\text { social and } \\
\text { technological } \\
\text { innovation to adapt to } \\
\text { the new normal. }\end{array}$ & $\begin{array}{l}\text { - Refocus of applied } \\
\text { research and } \\
\text { innovation activities } \\
\text { to aid sectors } \\
\text { suffering from the } \\
\text { crisis. } \\
\text { - Significant lack of } \\
\text { research funds } \\
\text { provided by those } \\
\text { industries in survival } \\
\text { mode. } \\
\text { Coping with the } \\
\text { crisis negatively } \\
\text { affects research } \\
\text { output. }\end{array}$ \\
\hline 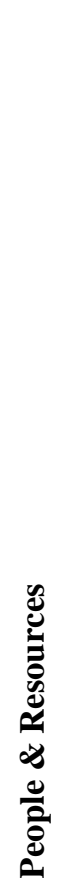 & $\begin{array}{l}\text { - } \text { Rapid employee } \\
\text { return to work } \\
\text { routines } \\
\text { pre-COVID } 19 \\
\text { state. } \\
\text { - Funding to remain } \\
\text { unchanged with } \\
\text { internal } \\
\text { reallocation to } \\
\text { focus on ensuring } \\
\text { the system is } \\
\text { prepared for } \\
\text { future crises. } \\
\text { Institutionalize } \\
\text { business } \\
\text { continuity and } \\
\text { disaster recovery. }\end{array}$ & $\begin{array}{l}\text { Employees } \\
\text { struggle with } \\
\text { getting back to } \\
\text { normal routines } \\
\text { due to fear from } \\
\text { another wave of } \\
\text { infection. } \\
\text { - } \quad \text { Funding is likely to } \\
\text { suffer a cut but not } \\
\text { a significant one. } \\
\text { Yet, internal } \\
\text { reallocation is } \\
\text { highly likely to } \\
\text { recover held off } \\
\text { projects. } \\
\text { Increased reliance } \\
\text { on technology for } \\
\text { all aspects of HCT } \\
\text { business and } \\
\text { support operations. }\end{array}$ & 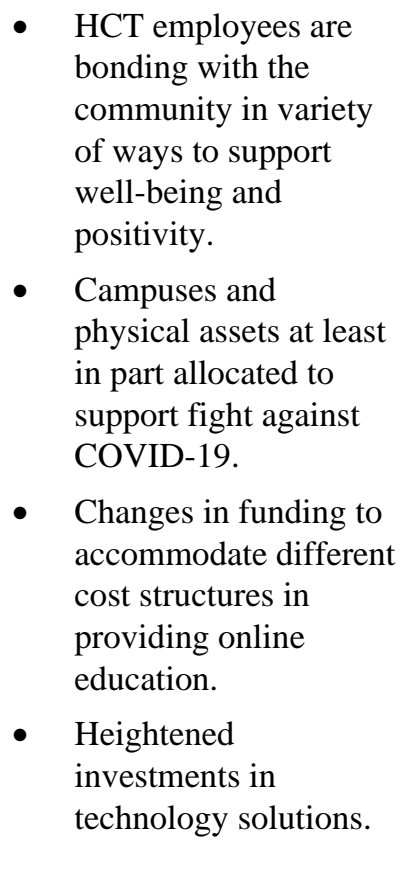 & $\begin{array}{l}\text { Work-From-Home } \\
\text { continues. } \\
\text { - High resignations } \\
\text { from faculty and } \\
\text { staff wanting to } \\
\text { return home due to } \\
\text { safety concerns. } \\
\text { - Campuses converted } \\
\text { to health care \& } \\
\text { medical quarantine } \\
\text { facilities. } \\
\text { Drastic funding cuts } \\
\text { by the government } \\
\text { leading to cuts in } \\
\text { salaries and projects } \\
\text { funding. }\end{array}$ \\
\hline
\end{tabular}

As shown, Table 2 give a summary of the implications of the four scenarios on HCT grouped by the above-mentioned four-core business and support areas.

The essence of scenario planning is to imagine alternative futures based on a deep analysis of trends and patterns identified at present. For HCT's responses to these scenarios to be holistic and comprehensive, a further analysis to these four scenarios was conducted to demonstrate the opportunities and challenges each brings. The Divine Mercy scenario involved the rapid acceleration in technology adoption to improve robustness and resilience as an opportunity (P1), while the challenge was retaining lessons learned for the future (C1). The Recovery Mode scenario saw an increase in research and entrepreneurship funding to develop capabilities in critical sectors as an opportunity (P2) to leverage on. This opportunity interconnected with the challenge presented by this scenario, which was Job availability limited to critical sectors (C2). The third scenario, New Norm, presented a high demand for accelerated 
innovations as an opportunity (P3) and operationalizing new work methods as a challenge (C3). While the Survival of the Fittest scenario presented an escalated value of competency-based education to backfill talent as an opportunity (P4) and reduced government funding, was considered a foreseeable challenge (C4).

\subsection{Proactive Strategic Options}

In order for HCT's to leverage the scenario planning exercise to address its focal issue, it was vital to back-cast the opportunities and challenges presented by these four scenarios, into a strategic design process that yielded specific strategic options across all four business and support areas identified.

Table 3a. Student Success Proactive Strategic Options

\begin{tabular}{|c|c|c|c|c|c|c|c|c|}
\hline \multirow[t]{2}{*}{ STRATEGIC OPTION } & \multicolumn{2}{|c|}{$\begin{array}{l}\text { DIVINE } \\
\text { MERCY }\end{array}$} & \multicolumn{2}{|c|}{$\begin{array}{l}\text { RECOVERY } \\
\text { MODE }\end{array}$} & \multicolumn{2}{|c|}{$\begin{array}{l}\text { NEW } \\
\text { NORM }\end{array}$} & \multicolumn{2}{|c|}{$\begin{array}{l}\text { SURVIVAL } \\
\text { OF THE } \\
\text { FITTEST }\end{array}$} \\
\hline & P1 & $\mathrm{C} 1$ & $\mathrm{P} 2$ & $\mathrm{C} 2$ & P3 & $\mathrm{C} 3$ & $\mathrm{P} 4$ & $\mathrm{C} 4$ \\
\hline $\begin{array}{l}\text { Re-focus employability efforts by targeting } \\
\text { employers in COVID-19 proof sectors }\end{array}$ & & $\sqrt{ }$ & & $\sqrt{ }$ & & & & \\
\hline $\begin{array}{l}\text { Make available one-to-one and group online } \\
\text { wellbeing student counseling }\end{array}$ & $\sqrt{ }$ & & & & & & & \\
\hline $\begin{array}{l}\text { Engage students to co-design online Campus } \\
\text { Life services }\end{array}$ & $\sqrt{ }$ & & & & $\sqrt{ }$ & $\sqrt{ }$ & & \\
\hline Establish an online tutoring program. & $\sqrt{ }$ & & & & & & & \\
\hline $\begin{array}{l}\text { Re-evaluate program offerings and } \\
\text { admission requirements }\end{array}$ & & $\sqrt{ }$ & & $\sqrt{ }$ & $\sqrt{ }$ & & & $\sqrt{ }$ \\
\hline $\begin{array}{l}\text { Ensure successful transition to a Digital } \\
\text { Campus environment for fresh high school } \\
\text { students }\end{array}$ & $\sqrt{ }$ & $\sqrt{ }$ & & & $\sqrt{ }$ & $\sqrt{ }$ & & \\
\hline
\end{tabular}

Table 3b. Teaching \& Learning Proactive Strategic Options

\begin{tabular}{|c|c|c|c|c|c|c|c|c|}
\hline \multirow[t]{2}{*}{ STRATEGIC OPTION } & \multicolumn{2}{|c|}{$\begin{array}{l}\text { DIVINE } \\
\text { MERCY }\end{array}$} & \multicolumn{2}{|c|}{$\begin{array}{l}\text { RECOVERY } \\
\text { MODE }\end{array}$} & \multicolumn{2}{|c|}{$\begin{array}{c}\text { NEW } \\
\text { NORM }\end{array}$} & \multicolumn{2}{|c|}{$\begin{array}{l}\text { SURVIVAL } \\
\text { OF THE } \\
\text { FITTEST }\end{array}$} \\
\hline & P1 & $\mathrm{C} 1$ & P2 & $\mathrm{C} 2$ & P3 & $\mathrm{C} 3$ & P4 & $\mathrm{C} 4$ \\
\hline $\begin{array}{l}\text { Plan for a Low-Density Campus using } \\
\text { blended learning where lab components only } \\
\text { are delivered on campus }\end{array}$ & $\sqrt{ }$ & & & & & $\sqrt{ }$ & & \\
\hline $\begin{array}{l}\text { Review all courses and programs for } \\
\text { effective online deliverability }\end{array}$ & & $\sqrt{ }$ & & & $\sqrt{ }$ & $\sqrt{ }$ & $\sqrt{ }$ & \\
\hline $\begin{array}{l}\text { Develop and implement marketing plans for } \\
\text { professional track programs and Health } \\
\text { Sciences expansion }\end{array}$ & & & & $\sqrt{ }$ & $\sqrt{ }$ & & $\sqrt{ }$ & \\
\hline $\begin{array}{l}\text { Review and revise program content, course } \\
\text { assessment strategies and pedagogies for } \\
\text { blended model compatibility }\end{array}$ & $\sqrt{ }$ & $\sqrt{ }$ & & & $\sqrt{ }$ & & $\sqrt{ }$ & \\
\hline $\begin{array}{l}\text { Develop and implement plan for } \\
\text { micro-credentials and work placement } \\
\text { model }\end{array}$ & $\sqrt{ }$ & & & $\sqrt{ }$ & $\sqrt{ }$ & & $\sqrt{ }$ & \\
\hline
\end{tabular}


Table 3c. Research \& Innovation Proactive Strategic Options

\begin{tabular}{|c|c|c|c|c|c|c|c|c|}
\hline \multirow[t]{2}{*}{ STRATEGIC OPTION } & \multicolumn{2}{|c|}{$\begin{array}{l}\text { DIVINE } \\
\text { MERCY }\end{array}$} & \multicolumn{2}{|c|}{$\begin{array}{c}\text { RECOVERY } \\
\text { MODE }\end{array}$} & \multicolumn{2}{|c|}{$\begin{array}{c}\text { NEW } \\
\text { NORM }\end{array}$} & \multicolumn{2}{|c|}{$\begin{array}{c}\text { SURVIVAL } \\
\text { OF THE } \\
\text { FITTEST }\end{array}$} \\
\hline & P1 & C1 & $\mathbf{P 2}$ & C2 & P3 & C3 & P4 & $\mathrm{C4}$ \\
\hline $\begin{array}{l}\text { Strengthen the support to entrepreneurial } \\
\text { activities to compensate for the major losses } \\
\text { of SMEs }\end{array}$ & $\sqrt{ }$ & $\sqrt{ }$ & $\sqrt{ }$ & $\sqrt{ }$ & $\sqrt{ }$ & & $\sqrt{ }$ & \\
\hline $\begin{array}{l}\text { Identify applied research themes aligned } \\
\text { with the UAE post-COVID-19 era national } \\
\text { priorities }\end{array}$ & $\sqrt{ }$ & & $\sqrt{ }$ & & $\sqrt{ }$ & & & \\
\hline $\begin{array}{l}\text { Engage industry and government with } \\
\text { innovation-driven quick wins to tackle post } \\
\text { COVID-19 emerging needs }\end{array}$ & $\sqrt{ }$ & & $\sqrt{ }$ & & $\sqrt{ }$ & $\sqrt{ }$ & $\sqrt{ }$ & $\sqrt{ }$ \\
\hline $\begin{array}{l}\text { Create a solid applied research network to } \\
\text { enable agile delivery of results leveraging } \\
\text { international partners }\end{array}$ & $\sqrt{ }$ & & $\sqrt{ }$ & & & $\sqrt{ }$ & & \\
\hline $\begin{array}{l}\text { Nurture a prolific culture of intrapreneurship } \\
\text { within HCT through largescale adoption of } \\
\text { its Innovation Management Platform }\end{array}$ & $\sqrt{ }$ & $\sqrt{ }$ & & & $\sqrt{ }$ & & & \\
\hline
\end{tabular}

Table 3d. People \& Resources Proactive Strategic Options

\begin{tabular}{|c|c|c|c|c|c|c|c|c|}
\hline \multirow[t]{2}{*}{ STRATEGIC OPTION } & \multicolumn{2}{|c|}{$\begin{array}{l}\text { DIVINE } \\
\text { MERCY }\end{array}$} & \multicolumn{2}{|c|}{$\begin{array}{c}\text { RECOVERY } \\
\text { MODE }\end{array}$} & \multicolumn{2}{|c|}{$\begin{array}{c}\text { NEW } \\
\text { NORM }\end{array}$} & \multicolumn{2}{|c|}{$\begin{array}{l}\text { SURVIVAL } \\
\text { OF THE } \\
\text { FITTEST }\end{array}$} \\
\hline & P1 & C1 & $\mathbf{P 2}$ & $\mathrm{C2}$ & $\mathbf{P 3}$ & $\mathbf{C 3}$ & P4 & $\mathrm{C4}$ \\
\hline $\begin{array}{l}\text { Institutionalize Work-From-Home practice } \\
\text { through the development of related policy } \\
\text { and guidelines }\end{array}$ & $\sqrt{ }$ & $\sqrt{ }$ & & & & $\sqrt{ }$ & & \\
\hline $\begin{array}{l}\text { Redesign campuses to allow for accessibility } \\
\text { control, distancing, and hygiene measures }\end{array}$ & & $\sqrt{ }$ & & & & $\sqrt{ }$ & & \\
\hline $\begin{array}{l}\text { Institutionalize recruitment practices of } \\
\text { adjunct and fulltime faculty from their home } \\
\text { base }\end{array}$ & & & & & & $\sqrt{ }$ & & $\sqrt{ }$ \\
\hline $\begin{array}{l}\text { Review of existing cost structures and } \\
\text { allocations to align with new priorities }\end{array}$ & & $\sqrt{ }$ & $\sqrt{ }$ & & $\sqrt{ }$ & $\sqrt{ }$ & & $\sqrt{ }$ \\
\hline $\begin{array}{l}\text { Review of all existing policies \& procedures } \\
\text { and introduction of new ones to improve } \\
\text { agility and flexibility }\end{array}$ & & $\sqrt{ }$ & $\sqrt{ }$ & & $\sqrt{ }$ & $\sqrt{ }$ & & \\
\hline
\end{tabular}

As shown in Tables 3a, b, c, and d, these strategic options were analyzed for fit and alignment in terms of leveraging the opportunities and coping with the challenges presented by the four scenarios in a matrix structure.

The above analysis showed that each of the designed strategic options addresses one or more of the opportunities and challenges presented by the four scenarios. Nevertheless, as new opportunities or challenges were identified, these strategic options were flexible enough to adapt. Furthermore, continuous scanning of the environment at the macro and micro levels needed to be adopted to refresh these scenarios, their features, implications, and their back-casted strategic options.

All of the above-mentioned indicators, statistics, and modifications coupled with HCT's early investments in educational technologies with an ecosystem perspective that was fully aligned with HCT's and the UAE digital enablement strategy, were all key factors behind the smooth transition to full online operations in such a short time. 
A robust digital infrastructure, with a variety of digital tools and applications and early investment in faculty digital readiness through accredited professional development and certification programs, all paid off. Students' relatively high satisfaction rates with online teaching and learning was highly due to their Z-generation characteristics, and their acknowledgement of the necessity to acquire digital skills that were highly in demand by employers. What remains to be a challenge in this full mode of online teaching and learning is the delivery of applied lab-based activities. In the absence of virtual simulations that could effectively replace human touch and physical presence, blended learning would seem to be the most optimal teaching and learning model.

\section{Concluding Remarks and Future Recommendations}

COVID-19 accelerated the use of technology in all areas of business including education like never before. HCT's readiness and seamless transition to full online delivery, however, is an outcome due to a number of success factors established over the past five years, and laid out in this case study.

Critically important while ensuring business continuity, is to consider future forward planning. Envisioning future scenarios and preparing the organization for them, is a practice that should be deployed in parallel to emergency response efforts. Subsequently, HCT scenarios were developed and analyzed for implications on its operations for the upcoming Academic Year 2020/2021. Opportunities and challenges of each scenario assessed and back casted into specific strategic options for HCT to undertake to be better prepared for any scenario as when it emerges.

It is necessary to conduct a comparative analysis between the effects of the online delivery model on students' achievement of learning outcomes versus a traditional face-to-face in class delivery. Another key area for investigation is to look at effective digital assessment strategies for lab-based content in a distance or online learning mode and their implications on student success. Finally, the post COVID-19 era, is perceived to be an era of heightened technological innovations in all sectors and industries. This was the case after each of the large high impact global crisis from the Great Depression in the $20^{\text {th }}$ century to the current COVID-19 pandemic. As such, introducing technological innovations to shape a new future for education overall, and higher education in particular, would be a major area for further research and study.

\section{Acknowledgements}

This paper is produced in accordance with the outcomes of strategic transformation and initiatives of the Higher Colleges of Technology in the United Arab Emirates. The authors of this paper extend their appreciation and gratitude to the HCT leadership and community for their valuable contribution.

\section{References}

Allen, I. E., \& Seaman, J. (2016). Online report card: Tracking online education in the United States. Babson Survey Research Group and Quahog Research Group LLC. Retrieved from https://files.eric.ed.gov/fulltext/ED572777.pdf

Alshamsi, A. (2020). On adapting to the impact of technological change and lifelong learning. Oxford Business Group. $\quad$ Retrieved from https://oxfordbusinessgroup.com/views/abdullatif-al-shamsi-president-ceo-higher-colleges-technology

Bernard, R. M., Abrami, P. C., Lou, Y., Borokhovski, E., Wade, A., Wozney, L., Wallet, P.A., Fiset, M., \& Huang, B. (2004). How does distance education compare with classroom instruction? A meta-analysis of the empirical literature. Review of Educational Research, 74(3), 379-439. https://doi.org/10.3102/00346543074003379

Blau, A., \& Schwartz, P. (2020). The world remade by COVID-19: Thrive scenarios for resilient leaders $3-5$ years. Published by Deliotte and Salesforce. Retrieved from https://www2.deloitte.com/content/dam/Deloitte/global/Documents/About-Deloitte/COVID-19/Thrive-scenario s-for-resilient-leaders.pdf

Cavanaugh, C. (2001). The effectiveness of interactive distance education technologies in $\mathrm{K}-12$ learning: A meta-analysis. International Journal of Educational Telecommunications, 7(1), 73-78. Retrieved from https://www.learntechlib.org/primary/p/8461/.

Costello, K. (2019). Gartner Identifies the Top 10 Strategic Technologies Impacting Higher Education in 2019. Retrieved

from https://www.gartner.com/en/newsroom/press-releases/2019-03-26-gartner-identifies-the-top-10-strategic-techno logies- 
Garrison, R., \& Kanuka, H. (2004). Blended learning: Uncovering its transformative potential in higher education. The Internet and Higher Education, Volume 7, Issue 2, 2nd Quarter 2004, Pages 95-105 https://doi.org/10.1016/j.iheduc.2004.02.001

Higher Colleges of Technology Education Technology Focal Strategy Retrieved from http://www.hct.ac.ae/content/uploads/02_Education_Technology_FocalStrategy2017_2021.pdf

Johnson, S. D., \& Aragon, S. R. (2003). An instructional strategy framework for online learning environments. New directions for adult and continuing education, 2003(100), 31-43. https://doi.org/10.1002/ace.117

Johnson, S. D., Aragon, S. R., \& Shaik, N. (2000). Comparative analysis of learner satisfaction and learning outcomes in online and face-to-face learning environments. Journal of interactive learning research, 11(1), 29-49. Retrieved from https://www.learntechlib.org/primary/p/8371/

Means, B., Toyama, Y., Murphy, R., Bakia, M., \& Jones, K. (2009). Evaluation of evidence-based practices in online learning: A meta-analysis and review of online learning studies. Retrieved from https://www2.ed.gov/rschstat/eval/tech/evidence-based-practices/finalreport.pdf

Moore, M. (1994). Administrative barriers to adoption of distance education. The American Journal of Distance Education, 8(3), 1-4. https://doi.org/10.1080/08923649409526862

Muir, Milthorpe, Stone, Dyment, Freeman and Hopwood. (2019). Chronicling engagement: students' experience of online learning over time. Distance Education Volume 40, 2019 - Issue 2 Pages 262-277 https://doi.org/10.1080/01587919.2019.1600367

Navarro, P., \& Shoemaker, J. (1999). The power of cyberlearning: An empirical test. Journal of computing in Higher Education, 11(1), 29-54. https://doi.org/10.1007/BF02940841

Palmer, E. J., \& Devitt, P.G. (2007). A method for creating interactive content for the iPod, and its potential use as a learning tool: Technical Advances. BMC Med Educ 7, 32(2007). https://doi.org/10.1186/1472-6920-7-32

Prime Minister's Office (2019) The Fifty-year Charter. Retrieved from https://www.mbrmajlis.ae/50-en/The\%20Fifty-Year\%20Charter.pdf

Prime Minister's Office (2015). UAE National Innovation Strategy Retrieved from https://www.moei.gov.ae/en/innovation/innovation-strategy.aspx

Prime Minister's office (2017). UAE Strategy for Artificial Intelligence Retrieved from https://u.ae/en/about-the-uae/strategies-initiatives-and-awards/federal-governments-strategies-and-plans/uae-stra tegy-for-artificial-intelligence

Smeaton, A. F., \& Keogh, G. (1999). An analysis of the use of virtual delivery of undergraduate lectures. Computers \& Education, 32(1), 83-94. https://doi.org/10.1016/S0360-1315(98)00052-9

Smyrnova-Trybulska, E. (2019). E-learning-Evolution, Trends, Methods, Examples, Experience. International Conference e-learning 2019. ISBN: 978-989-8533-88-3. Retrieved from https://www.researchgate.net/profile/Allam_Hamdan2/publication/335375315_THE_IMPACT_OF_E-LEARNI NG_ON_LEARNER_KNOWLEDGE_SHARING_QUALITY/links/5e1e23ec92851c3cbe652e50/THE-IMPA CT-OF-E-LEARNING-ON-LEARNER-KNOWLEDGE-SHARING-QUALITY.pdf\#page $=176$

Telecommunication Regulatory Authority. (2015). The National Plan for UAE Smart Government Goals. Retrieved from https://u.ae/-/media/mGov/UAE-TRA-mGov-Strategy-en-(5).ashx?la=en

Twigg, C. A. (2001). Innovations in online learning: Moving beyond no significant difference. Center for Academic Transformation, Rensselaer Polytechnic Institute. Retrieved from https://www.thencat.org/Monographs/Innovations.html

Yang, Y., \& Cornelious, L. F. (2004). Preparing Instructors for Quality Online Instruction. Retrieved September 10, 2008. https://www.westga.edu/ distance/ojdla/spring81/yang81.htm

\section{Copyrights}

Copyright for this article is retained by the author(s), with first publication rights granted to the journal.

This is an open-access article distributed under the terms and conditions of the Creative Commons Attribution license (http://creativecommons.org/licenses/by/4.0/). 